\title{
Wunderlich, Schelling and the History of Medicine
}

\author{
By Owsei Temkin, Baltimore
}

1

WUNDERLICH is remembered as one of the founders of clinical thermometry, as an early fighter for scientific medicine in Germany, and as a spirited historian of medicine. It is, therefore, not surprising to find one of his early scientific publications, "Fever," given the subtitle: "Historical-physiological investigations". ${ }^{1}$ The historical part of the long essay appeared in the same volume (though not the same issue) of the Archiv für physiologische Heilkunde which was prefaced by the famous attack of the editors on contemporary German medicine, ${ }^{2}$ and which also contained Wunderlich's article on medical journalism. ${ }^{3}$ The latter article initiated a controversy with HAESER over the aims of medical historiography. Wunderlich insisted on a history of medicine that would be useful, in that it would trace those ideas which were of concern to the current theory and practice of medicine. ${ }^{4}$ From this point of view, Wunderlich's method, as well as his remarks on medical historiography in his essay on fever, deserve some attention.

Wunderlich pursues his historical discussion of fever from Hippocrates to Johannes MüLler (whose physiological interpretation of fever as an affection of the spinal cord impressed him as "the height of the physiological point of view"), ${ }^{5}$ Stilling, Henle, and Stannius. ${ }^{6}$ Summing up the historical part of his investigation, Wunderlich asks whether it represents a mere list of errors, or whether the history of the doctrine of fever is a developmental history ("Entwicklungsgeschichte"). He affirms the latter alternative, though he denies a regular and steady change. "To attempt always in

1 Carl August Wunderlich, Das Fieber. Historisch-physiologische Untersuchungen, Arch.physiol. Heilk. 1 (1842) 266-294 and 351-400, 2 (1843) 6-62.

2 Roser and WunderLich, Über die Mängel der heutigen deutschen Medicin und über die Nothwendigkeit einer entschieden wissenschaftlichen Richtung in derselben, ibid., pp. i-xxx.

3 Wunderlich, Die medicinische Journalistik, ibid., pp. 1-42.

4 Owsei Temkin and C.LiLIan Temkin, Wunderlich versus Haeser: a controversy over medical history, Bull. Hist. Med. 32 (1958) 97-104. Here (p. 103) literature on contemporary historiography is cited.

5 WunderLich, Das Fieber, p. 398.

6 ib., pp.399 and (1843) p.10, footnote. 
every detail and peculiarity to demonstrate the idea which is unconsciously asserting itself is an unnatural manner of dealing with history, totally at variance with an objective view of events. It is not in such fortuitous matters that the historian must find the development of the idea; he must rather demonstrate that it proceeds on its way in spite of accidents and episodic incidents".?

To speak of "Entwicklungsgeschichte" and to trace the development of a concept or an idea, was not uncommon in 1842. But in the opening pages of his essay Wunderlich supplied a basis for his historical thinking which shows some personal characteristics.

The essay opens with the following quotation from the philosopher Schelling: "In accordance with a general rule, Science, like every kind of culture, seems after the age of unconsciousness to arrive at conscious clarity and fulfillment only by way of opposition and splitting off." 8 Wunderlich says that he "put this sentence of the celebrated philosopher of our time at the head and would like to use it as a motto and as a shield for the following essay." The sentence is to serve as a motto because "it announces the historical and psychological fact" whose validity for some part of medical science Wunderlich is going to show. Besides, the sentence is to shield him against the increasing custom of considering morally suspect all medicohistorical research that does not appear in the garb of enthusiasm, tactfully cloaking the past. ${ }^{9}$

For Wunderlich, scientific progress is not an arithmetical progression. It is an organic process; it consists in a continuous sequence of annihilation and formation. What comes later spares as much of what went before as it needs for its own existence. Of the ideas of our predecessors few only re-

7 ib., p. 399f. (translation by C.LiLian Temkin). For the convenience of the English reader, quotations are given in translation; lack of space unfortunately forbids the addition of the German original.

8 Wunderlich, op.cit., p.266, with reference in the footnote. The quotation is from Schelling's Vorläufige Bezeichnung des Standpunktes der Medicin nach Grundsätzen der Naturphilosophie, Jahrbücher der Medicin als Wissenschaft, ed. by A.F.MARGUS and F. W.J.Schelling, Tübingen, Cotta, 1806, 1: 165-206, where it reads (p.166): «Nach einem allgemeinen Gesetz scheint die Wissenschaft, wie jede andre Art der Bildung, nach dem Zeitalter der Bewußtlosigkeit erst durch Gegensatz und Trennung hindurch zur selbstbewußten Klarheit und Vollendung gelangen zu müssen.» Wunderlich does not quote accurately; in particular he omits the word « andre» before «Art der Bildung, » and he ends the quotation with «können, » instead of «müssen.»

9 WUNDERLICH, $l$. $c$. 
main, and even they are modified. On the other hand, the steps in the development can be traced not only through various periods; these steps also find their representation in our own time. Historical investigation, therefore, embraces present problems. In the present era, examples "for all and sundry steps (Sprossen) of the intellectual ladder will [easily] be discovered: from the lowest, most limited aspect to the clear recognition and penetration of the subject," i.e. fever. ${ }^{10}$ This, we may add, is a parallel in the realm of ideas to the law of recapitulation in biology.

Wunderlich refers to the investigation of the origin and development of scientific ideas, concepts, and knowledge as "the scientific treatment of history." Such scientific treatment enjoys much greater license than "antiquarian historiography." For the scientific treatment, questions of priority will be subordinate. Representative men who were able to handle the idea in its purest, most comprehensive, and most influential form are of greater interest than are men who showed the first traces of an idea. ${ }^{11}$

As Wunderlich understands it, history will not try to belittle the talent and the relative merits of our predecessors. But it will not claim for them unsurpassable excellence or suggest a return to their so-called classicality. History is the judge of things, for it is history which has judged the errors of the past. The mere fact that we exist, that we know the past and yet think differently, suffices to condemn the past. "Retrogression is only possible in science if we forget and ignore our predecessors ... The man who becomes enthusiastic about them and takes them as his model remains stuck at their level. He who recognizes their errors steps over them. What we need, what raises us above the past and makes us worthy of the present, is the recognition of where and why man has failed." 12

2

The history of science as a critical debate with earlier opinions goes back at least as far as Aristotle. But in the form given by Wunderlich, it rests on assumptions that belong to the period around 1800. Wunderlich's image of the history of ideas as a continuous destruction and creation, where each step leaves its mark so that all the steps still exist in the present, has its

10 ib., p. 268.

11 ib.

$12 i b .$, p. 267 (translation by C.LiLian TeMkin). 
counterpart in the ideas of Herder, Kielmeyer, Schelding and Hegel, where history and ontogeny blended into a picture of "development". ${ }^{13}$ This picture, to which historical, philosophical, and biological work had contributed, could be expected to be in Wunderlich's mind, and he could rightly cite Schelling as a source of his philosophy of history.

In 1841, Schelling had followed a call to the University of Berlin, where he was welcomed with great expectations. Thus Wunderlich's reference to "the celebrated philosopher of our time" is understandable. But there was more involved than an opportune gesture. When Wunderlich turns to the history of the doctrine of fevers in Germany, he says that many an ingenious attempt at a better comprehension of what is called fever is found among German physicians in the beginning of the nineteenth century. Unfortunately, their wish to investigate a priori the final principles of things led to a neglect of detailed knowledge, without which all speculation in medicine is useless and fatal. Such a criticism of speculative medicine is not surprising, but the subsequent admission is significant: "To be sure, sometimes along these paths [i.e. a priori speculations] an ingenious idea was also gained regarding the conditions of fever; for it cannot be denied that in the beginning of this century, thoughtful, philosophical men had turned to the problems of medicine." 14

Wunderlich then continues with his criticism of this phase of German medicine. Yet he is relatively restrained; his full wrath is reserved for the following generation: "This fanciful era was followed by a period which offers even fewer results to the historian looking for progress; it did not even produce speculations, leave alone positive enrichment. This was the intellectually barren time of medical eclecticism. To look back upon this sad desert is painful. Whereas our neighbors pursued theoretical discussions and exact research with enthusiastic zeal, the German medical writings of this period (third decade and beginning of the fourth) with few exceptions are the expression of a hopeless intellectual poverty, of a repellent absence of taste, and a complete lack of talent for observation, even of the urge to observe." 15

13 Owsei Temkin, German concepts of ontogeny and history around 1800, Bull. Hist. Med., 24. (1950) 227-246.

14 WunderLICH, op.cit., p. 380. In contrast to Germany, WunderLich characterized English modern medicine as "poor in ideologies" (p. 376: «arm an Ideologieen»).

15 ib., p. $380 f$. 
Wunderlich's relative respect for the early romantic era (in contrast to the period from about 1820 to 1834, when the first volume of MüLLER's Handbook of Physiology appeared) is corroborated by his remarks on the Brunonian system, on Röschlaub, and on some adherents of the school of Naturphilosophie. "The Brunonian doctrine contains the basic formula of physiological medicine;" it could have led to a transformation of medical science, had it not been for the inaptness of its followers. Röschlaub was different; he tried to elaborate his theory of excitement ("Erregungstheorie") in a physiological sense. "He can be regarded as the German who, earlier than anybody else, clearly conceived the relevancy of a physiological medicine." 16 The Erregungstheorie imperceptibly passes into the doctrines of the so-called school of Naturphilosophie, and "the writings of these theoreticians contain many a good remark, many a good idea." 17 In this context Wunderlich quotes books by Troxler (of 1803) and Kieser (of 1817). To be sure, Wunderlich is thinking above all of the theory of fever, and his praise is followed by criticism of the distance from concrete problems and of the lack of objective observation. Nevertheless, with all its reservations this acknowledgment is worth noting.

Wunderlich does not stand alone among his reforming contemporaries in seeing a good side in the German medicine of the early nineteenth century. JACOB Henle, in the opening article of the competing Zeitschrift für rationelle Heilkunde, ${ }^{18}$ which he began to edit together with C.PFeuffer in 1844, also made rational medicine depend on physiology. Fundamentally the two are even identical. The study of the abnormal influences teaches something about the forces of the healthy organism. For a short time, this was forgotten when Naturphilosophie introduced the genetic point of view into medicine and thereby opened an entirely new field for research. On the basis of the development of organs and by the comparison of parts which correspond to one another all through the scale of organisms, one inquired into the significance of the organs and the reason of their existence, rather than into their purpose and use. This led to physiological explanations, to an insight into the plan of organization and what is essential in every compound organ. "One must have experienced what joy results from

16 ib., p.387. For the appreciation of Brown's system see also p. 357.

17 ib., p. 388.

18 J.Henle, Medizinische Wissenschaft und Empirie, Zeitschrift für rationelle Medicin (Schultheß, Zürich) 1 (1844) 35. 
seeing the same idea embodied in a thousand forms and the most complicated structure developing from the simplest beginnings, in order to understand, and to pardon, the zeal with which the coryphaei of physiology followed the direction of comparative anatomy exclusively." 19

This reference to the work of Goethe, Doellinger, Meckel, and Johannes MüLler is not surprising from Müller's pupil and friend. Henle was more closely connected with the past than were Wunderlich and such pupils of Müller's as Virchow, Helmholtz, DuBois-Reymond, and BrücKe. Henle too adds that medicine profited next to nothing from that movement, except for a theory of congenital anomalies. A healthy reaction against the reveries of some philosophical physiologists, important discoveries in the realm of physics, organic chemistry, and even of physiology had cured physiology of its one-sidedness and restored to honor the experimental method, which had been forgotten or even rejected. ${ }^{20}$

Henle's remarks merely go to show that Wunderlich did not stand alone among medical reformers in allowing a good side to the past, and undoubtedly many others could be cited. Henle does not define chronological boundaries, and perhaps this was not essential for him, since he was speaking of physiology, and particularly of that part of physiology which RuDOLPHI, as far back as 1821, had claimed for German scientists. ${ }^{21}$ Wunderlich, on the other hand, was speaking of medicine, with special reference to one subject, the doctrine of fever. The fact that, in 1842, a man of Wunderlich's stature could appeal to Schelling's authority, is interesting. That he perceived many different strands within the history of German medicine during the three and a half decades before 1834, strands which he evaluated differently, should induce us to pay attention to these various strands also, especially when we trace romantic influences in Germany or abroad. ${ }^{22}$

Would it be justifiable then to say that Wunderlich was indebted to Schelling and his Naturphilosophie? As stated before, Wunderlich, like so many historians of this time, was under the influence of the philosophy of

19 ib., p. 29.

20 On the rejection of physiological experiment see Owser Temkin, Basic science, medicine, and the romantic era, Bull. Hist.Med. 37 (1963) 97-129 (especially p. $120 \mathrm{ff}$.).

21 K.A. Rudolphi, Grundriß der Physiologie, vol. 1, Dümmler, Berlin 1821, p. 2. Rudolphi is thinking of general physiology.

22 In WunderLich's Geschichte der Medicin, Ebner und Seubert, Stuttgart 1859, the distinctions, though still present, appear weakened because of the greater historical distance. 
history which Schelling had helped to shape. But I do not believe that we have to establish close bonds between Wunderlich and Naturphilosophie in the field of medical science. Wunderlich's qualified respect for the latter, apart from the acknowledgment of individual sagacity, is largely due to his appreciation of a philosophical view of medicine. This appreciation is expressed in his Wien und Paris of 1841, where Wunderlich compared French and German science. German science, he states, is marked by an inclination to philosophical penetration. To be sure, the strong influence of the recent philosophical systems was largely misleading, yet "if only the poetical-philosophical ideas of the but recently passed period were to be changed for the sober tendency and the keen, unbiased logic of the present, incalculable profit could be foretold for medicine." ${ }^{23}$ German physiology, as Wunderlich thought, had partly solved this task already: indeed, a mere comparison of the physiology of a Johannes Müller with that of Magendie enabled one "to enjoy the salutary sentiment of patriotic pride." 24

In other words, Wunderlich demands a philosophical penetration of medical science, in preference to the unsystematic approach of positivistic fact-finding. But philosophy need not, and should not, be identified with "Naturphilosophie" in the historically restricted meaning of the word.

These ideas of Wunderlich's have some bearing on the historiography of medicine in Germany. It seems important to have an open mind for the positive effects of the philosophical movements of the early nineteenth century. Their influences should not be denied where they can be demonstrated. Nevertheless, Wunderlich's attitude raises doubts whether we are not sometimes going too far in this direction. The tendency towards systematization, often with pronounced metaphysical undertones, has long been observed in German science, especially of the nineteenth century. However we may explain this tendency, to see in it a constant after-effect of Naturphilosophie seems one-sided. Rather it would seem that Naturphilosophie itself was an early manifestation of the same tendency, of which the materialism of the mid-century, and many systematized theories were other manifestations. In as far as historical phenomena usually are interconnec-

${ }^{23}$ Carl August Wunderlich, Wien und Paris. Ein Beitrag zur Geschichte und Beurtheilung der gegenwärtigen Heilkunde in Deutschland und Frankreich, Ebner und Seubert, Stuttgart 1841, p.21.

24 ib., p.22. 
ted, such a view does not exclude connecting threads; on the other hand, it safeguards us from overrating their strength. Wunderlich favored a philosophical approach; he even complained that "the newest philosophy of our era has as yet had little effect upon us," i.e. on medical men. ${ }^{25}$ Thus he could perceive the kindred spirit in the work of Schelling and his contemporaries, and of the philosophically minded Johannes Müller, without himself being a romantic in medicine. ${ }^{26}$

25 ib., p. 21 : «So hat namentlich die neueste Philosophie unseres Zeitalters bis jetzt auf uns noch wenig gewirkt. » I do not know what philosophers, if any, Wunderlich has in mind.

${ }^{26}$ In some respects Wunderlich's attitude as sketched in this article makes him appear as a forerunner of Virchow; see ERwIN H. ACKERKNEcht, Rudolf Virchow, University of Wisconsin Press, Madison 1953, p.48, and especially p. $146 \mathrm{ff}$. 